\title{
Sistem Pengelolaan E-Commerce (SisPEC) Produk Adpers Art Community Kelurahan Sukatani Kecamatan Tapos Depok
}

\author{
Haryani $^{1}$, Nurvi Oktiani ${ }^{2}$, Taat Kuspriyono ${ }^{3}$, Ibnu Akil ${ }^{4}$ \\ 1,2,3,4 Universitas Bina Sarana Informatika, Indonesia \\ email: 1haryani.hyi@bsi.ac.id, 2nurvi.nvk@bsi.ac.id, 3taat.tat@bsi.ac.id, 4ibnu.ial@bsi.ac.id
}

\begin{abstract}
Abstrak
Penjualan online atau e-commerce merupakan suatu aplikasi yang dibangun untuk bisnis penjualan barang atau jasa yang menghubungkan antara penjual dan pembeli melalui transaksi elektronik dan membantu penjual dalam memasarkan produk dagangannya. Tujuan dari sosialisasi pengelolaan penjualan online ini adalah untuk memberikan pengarahan kepada anggota Adpers Art Community dalam proses pengelolaan penjualan online produk Adpers. Dalam menjalankan aktivitas kegiatan sehari-harinya Adpers Art mengalami beberapa kendala diantaranya pemasaran dan promosi yang belum maksimal dilakukan karena masih mengandalkan situs web pribadi, hal ini masih kurang efektif dan efisien dengan ditandai indikator bahwa masih banyaknya konsumen yang belum mengetahui Adpers Art ini, selain itu dari segi manajemen Produksi dan Inovasi Produk, yang mana diperlukannya suatu pemahaman dan pengelolaan hasil produksi dengan cara dan inovasi produk yang menjangkau seluruh kebutuhan dan keinginan konsumen dimana tidak hanya menjangkau 1 (satu) komunitas atau segmen konsumen saja tapi dapat menjangkau segmentasi pasar yang lain (seperti segmentasi yang dilihat dari jenis kelamin, gaya hidup, dan lain-lain), pada akhirnya dengan permasalahan diatas maka diperlukannya suatu solusi permasalahan bagi Adpers - Art agar kedepannya lebih dapat memaksimalkan pemasaran dan promosi serta Produksi yang memiliki Inovasi. Metode yang digunakan dalam kegiatan pengabdian masyarakat ini adalah dengan pemberian ceramah mengenai tata cara pengelolaan penjualan online yang baik dan benar. Hasil dari kegiatan pengabdian masyarakat ini adalah para anggota Adpers Art dapat melakukan pengelolaan penjualan online.
\end{abstract}

Kata Kunci: Pengelolaan, Penjualan, online

\section{Abstract}

Online sales or e-commerce is an application built for the business of selling goods or services that connects sellers and buyers through electronic transactions and helps sellers market their merchandise. The purpose of this online sales management socialization is to provide direction to Adpers Art Community members in the process of managing the online sales of Adpers products. In carrying out its daily activities, Adpers Art experiences several obstacles including marketing and promotions that have not been maximally carried out because they still rely on personal websites, this is still ineffective and efficient, marked by indicators that there are still many consumers who do not know this Adpers Art, besides in terms of Production and Product Innovation management, which requires an understanding and 
management of production results by means of and product innovation that reaches all the needs and desires of consumers where it does not only reach 1 (one) community or consumer segment but can reach other market segments (such as segmentation seen from gender, lifestyle, etc.), in the end with the above problems, a solution to the problem is needed for Adpers - Art so that in the future they can maximize marketing and promotion as well as Production that has Innovation. The method used in this community service activity is to give lectures on how to manage online sales that is good and correct. The result of this community service activity is that Adpers Art members can manage online sales.

Keywords: Management, Sales, online

\section{Pendahuluan}

Adpers Art merupakan komunitas yang terbentuk atas kesamaan hobi dan menuangkan karya seni kedalam media nyata, dimana khususnya menuangkan karya tersebut kedalam bentuk visual ke media kertas dan beberapa media lainnya yang berbentuk 3 (tiga) dimensi, komunitas yang beralamatkan di kelurahan sukatani kecamatan Tapos Kota Depok ini memiliki visi dan misi diantaranya menjadi sebuah usaha yang pertama di Indonesia dengan mengedepankan teknologi berbasis kreatifitas sehingga dapat menginspirasi banyak orang, adapun untuk gambaran struktural komunitas terdiri dari ketua yang bertugas dalam mengkoordinir dan bertanggung jawab terhadap seluruh aktivitas dalam Adpers Art, wakil ketua dengan tugas mengontrol anggota, Kepala Divisi Seni Visual bertugas dalam melakukan persiapan visualiasi sebelum dan saat event atau project berlangsung, proses produksi dilakukan dengan cara perancangan Design (Pola), pengolahan yang disederhanakan dengan menggunakan aplikasi atau software grafis/olah digital, pencetakan dengan menggunakan kertas bekas ataupun karton khusus, packing dan pemasaran. Pada prakteknya Aktivitas ataupun kegitan usaha yang dilakukan oleh Adpers - Art masih mengalami kendala diantaranya kegiatan Pemasaran dan Promosi yang belum maksimal dilakukan karena masih mengandalkan media melalui situs : https://adpers-art.blogspot.com, dimana dapat dikatakan masih belum efektif dan efisien dengan ditandai indikator bahwa masih banyaknya konsumen yang belum mengetahui keberadaan dari Adpers - Art ini, selain itu dari segi manajemen Produksi dan Inovasi Produk, yang mana diperlukannya suatu pemahaman dan pengelolaan hasil produksi dengan cara dan inovasi produk yang menjangkau seluruh kebutuhan dan keinginan konsumen dimana tidak hanya menjangkau 1 (satu) komunitas atau segmen konsumen saja tapi dapat menjangkau segmentasi pasar yang lain (seperti segmentasi yang dilihat dari jenis kelamin, gaya hidup, dan lain-lain), pada akhirnya dengan permasalahan diatas maka diperlukannya suatu solusi permasalahan bagi Adpers - Art agar kedepannya lebih dapat memaksimalkan pemasaran dan promosi serta Produksi yang memiliki Inovasi.

Saat ini perkembangan teknologi informasi dan komunikasi sudah dapat digunakan secara maksimal. Begitu juga dengan penggunaan internet mengalami banyak perubahan, tidak hanya sekedar bertukar data melalui perangkat keras (hardware) yang sudah umum digunakan, seperti personal computer (PC), laptop, atau 
smartphone, namun perlahan beralih ke berbagai peralatan yang ada di lingkungan manusia (Zubaidi, Wijaya, Irmawati, \& Arimbawa, 2019). Dalam usaha memasarkan produk di Adpers-Art diperlukan pengelolaan penjualan yang dapat menjangkau seluruh masyarakat baik dalam maupun luar negeri. Dalam mempromosikan produk, para pegawai mengalami kesulitan dalam penggunaan website akan lebih banyak dalam melihat harga barang karena harus menggantungkan, juga mempermudah proses mencari terlebih dahulu dalam buku besar, penggembangan dan dapat menghemat biaya (Hastanti, Purnama, \& Wardati, 2015). Dalam proses menjangkau pasar yang luas diperlukan suatu media untuk menyampaikan informasi kepada calon pelanggan, selain media untuk menyampaikan informasi sebaiknya didukung juga oleh sarana dan prasarana untuk mempermudah proses penyebar luasan informasi (Hidayat \& Ningrum, 2017).

Kondisi saat ini penggunaan internet di dunia bisnis sudah berubah fungsi yang awalnya hanya sebagai alat untuk pertukaran informasi secara elektronik sekarang menjadi alat untuk aplikasi strategi bisnis, seperti pemasaran dan pelayanan pelanggan (Thousani, Fauzi, \& Sunarti, 2015). Dengan merancang sebuah aplikasi sistem informasi penjualan secara online mampu menjawab beberapa masalah yang terjadi pada bisnis khususnya penjualan secara online (Nursari \& Immanuel, 2018).

Teknologi informasi dan komunikasi juga digunakan untuk sistem penjualan, salah satu fasilitas internet yaitu untuk melakukan penjualan online yang dikenal dengan istilah e-commerce (Susandi \& Sukisno, 2017). E-commerce adalah electronic commerce, merupakan kumpulan teknologi, aplikasi, dan bisnis yang menghubungkan perusahaan atau perseorangan sebagai konsumen untuk melakukan transaksi elektronik, pertukaran barang, dan pertukaran informasi melalui internet atau televisi, www, atau jaringan komputer lainnya (Thousani et al., 2015). Saat ini para pebisnis melakukan promosi sekaligus memasarkan produk-produk yang dijual dengan menggunakan e-commerce (Syah, Iqbal, \& Elveny, 2014).

Ada beberapa tujuan yang ingin dicapai dalam kegiatan pengabdian masyarakat ini diantaranya (1) Menciptakan kemampuan peserta pengabdian masyarakat dalam mengelola penjualan secara online (2) Menciptakan kemampuan dalam startegi pemasaran penjualan (Digital Online).

\section{Metode}

Kegiatan pengabdian masyarakat dilaksanakan dengan menggunakan metode one day workshop. Kegiatan pengabdian masyarakat dilakukan dengan memberikan ceramah dan pelatihan karena metode ini dapat memberikan kesempatan kepada para peserta untuk dapat langsung mempraktekkan terhadap materi yang disampaikan oleh tutor. Hal ini juga sesuai dengan peserta pengabdian masyarakat yang rata-rata sudah dewasa dan mudah untuk belajar sendiri tanpa didampingi. 


\section{Tabel 1}

Tahapan Kegiatan Pengabdian Kepada Masyarakat

\begin{tabular}{|c|c|c|c|c|}
\hline \multirow[t]{2}{*}{ No } & \multirow[t]{2}{*}{ Rencana Kegiatan } & \multicolumn{3}{|c|}{ Keterlibatan dalam Kegiatan } \\
\hline & & Dosen & Mahasiswa & Masyarakat \\
\hline 1 & $\begin{array}{l}\text { Survei dan pemetaan } \\
\text { kemampuan awal } \\
\text { peserta }\end{array}$ & $\begin{array}{l}\text { Merumuskan } \\
\text { instrument untuk } \\
\text { mengukur } \\
\text { kemampuan } \\
\text { peserta }\end{array}$ & $\begin{array}{l}\text { Membantu } \\
\text { melakukan survey }\end{array}$ & $\begin{array}{l}\text { Masyarakat } \\
\text { menyediakan } \\
\text { waktu dan } \\
\text { tempat untuk } \\
\text { melakukan } \\
\text { survey }\end{array}$ \\
\hline 2 & Pembuatan Modul & $\begin{array}{l}\text { Pembuatan konten } \\
\text { modul berdasarkan } \\
\text { hasil survey }\end{array}$ & $\begin{array}{ll}\text { Membantu } & \text { dalam } \\
\text { proses } & \text { layout } \\
\text { modul pelatihan }\end{array}$ & $\begin{array}{l}\text { Masyarakat } \\
\text { melakukan } \\
\text { verifikasi } \\
\text { terhadap modul } \\
\text { dari segi tata } \\
\text { bahasa }\end{array}$ \\
\hline 3 & Pelatihan & & & \\
\hline & $\begin{array}{l}\text { Pengenalan Penjualan } \\
\text { Online }\end{array}$ & $\begin{array}{l}\text { Memberikan } \\
\text { materi dan } \\
\text { melakukan demo }\end{array}$ & $\begin{array}{l}\text { Mendampingi } \\
\text { peserta ketika } \\
\text { melakukan praktik }\end{array}$ & $\begin{array}{l}\text { Masyarakat } \\
\text { mengikuti } \\
\text { workshop }\end{array}$ \\
\hline & $\begin{array}{l}\text { Pengenalan Aplikasi } \\
\text { Penjualan Online }\end{array}$ & $\begin{array}{l}\text { Memberikan } \\
\text { materi dan } \\
\text { melakukan demo }\end{array}$ & $\begin{array}{l}\text { Mendampingi } \\
\text { peserta ketika } \\
\text { melakukan praktik }\end{array}$ & $\begin{array}{l}\text { Masyarakat } \\
\text { mengikuti } \\
\text { workshop }\end{array}$ \\
\hline & $\begin{array}{lr}\text { Praktek } & \text { penggunaan } \\
\text { aplikasi } & \text { Penjualan } \\
\text { Online } & \end{array}$ & $\begin{array}{l}\text { Memberikan } \\
\text { materi dan } \\
\text { melakukan demo }\end{array}$ & $\begin{array}{l}\text { Mendampingi } \\
\text { peserta ketika } \\
\text { melakukan praktik }\end{array}$ & $\begin{array}{l}\text { Masyarakat } \\
\text { mengikuti } \\
\text { workshop }\end{array}$ \\
\hline 4 & Evaluasi & $\begin{array}{l}\text { Memandu } \\
\text { pengisian lembar } \\
\text { evaluasi }\end{array}$ & $\begin{array}{l}\text { Menyebarkan } \\
\text { lembar evaluasi }\end{array}$ & $\begin{array}{l}\text { Masyarakat } \\
\text { mengisi lembar } \\
\text { evaluasi }\end{array}$ \\
\hline
\end{tabular}

Tabel 2

Indikator Keberhasilan Kegiatan (Utama dan Pendukung)

\begin{tabular}{|c|c|c|c|}
\hline No & Indikator & $\begin{array}{l}\text { Base Line (sebelum } \\
\text { kegiatan) }\end{array}$ & Pencapaian setelah kegiatan \\
\hline 1 & $\begin{array}{l}\text { Kemampuan } \\
\text { menggunakan media } \\
\text { penjualan online }\end{array}$ & $\begin{array}{l}\text { Metode penjualan } \\
\text { masih dilakukan secara } \\
\text { manual }\end{array}$ & $\begin{array}{l}\text { Aplikasi penjualan online sudah } \\
\text { dimanfaatkan untuk usaha } \\
\text { penjualan produk. }\end{array}$ \\
\hline 2 & $\begin{array}{l}\text { Kemampuan } \\
\text { mengelola penjualan } \\
\text { secara online }\end{array}$ & $\begin{array}{lr}\text { Pengelolaan } & \text { data } \\
\text { penjualan } & \text { masih } \\
\text { dilakukan } & \text { secara } \\
\text { manual } & \\
\end{array}$ & $\begin{array}{l}\text { Sudah melakukan pengelolaan data } \\
\text { penjualan melalui aplikasi penjualan } \\
\text { online }\end{array}$ \\
\hline 3 & $\begin{array}{l}\text { Kemampuan } \\
\text { melakukan } \\
\text { marketing } \\
\text { online }\end{array}$ & $\begin{array}{lr}\text { Belum } & \text { memahami } \\
\text { startegi } & \text { digital } \\
\text { marketing } & \end{array}$ & $\begin{array}{l}\text { Sudah memahami startegi digital } \\
\text { marketing }\end{array}$ \\
\hline
\end{tabular}




\section{Hasil dan Pembahasan}

Tahapan pertama dalam kegiatan pengabdian masyarakat ini adalah melakukan survei terkait dengan pengelolaan penjualan yang selama ini dilakukan pada Adpers Art. Tujuan dilakukan survei ini adalah untuk membuat pemetaan terhadap kemampuan pengelolaan penjualan secara online. Survei dilakukan dengan penyebaran kuesioner kepada anggota Adpers Art Community sebanyak 15 responden.

Hasil survei menunjukkan sebagian besar anggota Adpers Art Community belum melakukan pengelolaan penjualan secara online, dan proses pemasaran masih dilakukan dengan cara dari mulut ke mulut.

Tabel 3 (Survei tahap awal)

\begin{tabular}{clc}
\hline $\mathbf{N o}$ & \multicolumn{1}{c}{ Indikator } & Hasil \\
\hline $\mathbf{1}$ & $\begin{array}{l}\text { Kemampuan } \\
\text { menggunakan media } \\
\text { penjualan online }\end{array}$ & $12 \%$ \\
\hline $\mathbf{2}$ & $\begin{array}{l}\text { Kemampuan } \\
\text { mengelola penjualan } \\
\text { secara online }\end{array}$ & $9 \%$ \\
\hline $\mathbf{3}$ & $\begin{array}{l}\text { Kemampuan } \\
\text { melakukan strategi } \\
\text { marketing secara } \\
\text { online }\end{array}$ & $10 \%$ \\
\hline
\end{tabular}

Tahapan kedua adalah sosialisasi pengelolaan penjualan online. Kegiatan pengabdian kepada masyarakat yang telah dilaksanakan pada Adpers Art Community dapat diketahui bahwa peserta komunitas ini belum banyak mengetahui mengenai pengelolaan data penjualan dan penjualan online pada sistem penjualan barang-barang yang ada di Adpers Art Community. Pemanfaatan internet belum sepenuhnya digunakan secara maksimal, rata-rata peserta komunitas menggunakan internet hanya sebatas mencari informasi, hiburan dan media sosial saja.

Kondisi kegiatan sosialisasi pengelolaan data penjualan dan penjualan online ini dapat dilihat pada gambar 1.

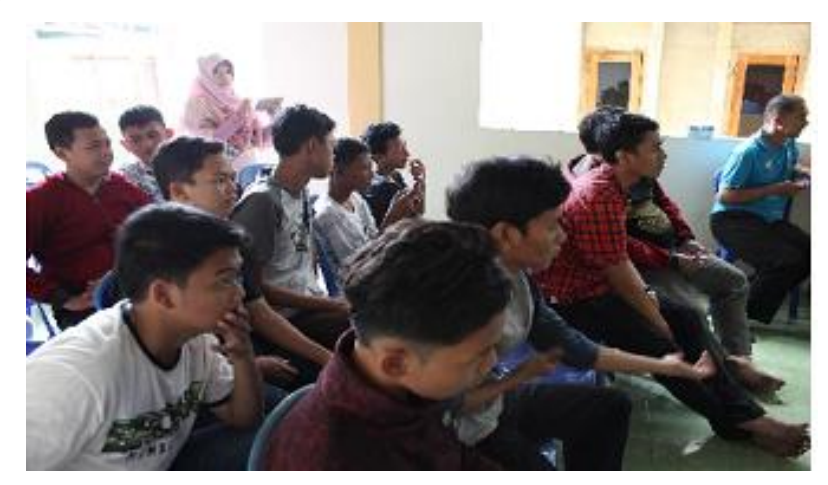

Gambar 1 Sosialisasi penggunaan e-commerce 
Dalam kegiatan pengabdian masyarakat ini, para peserta terlihat antusias sekali dalam mengikuti acara tersebut. Mereka sangat serius mengikuti karena materi yang disampaikan sangat bermanfaat bagi Adpers Art Community, sehingga permasalahan yang dihadapi saat ini dapat memecahkan kondisi yang ada.

Untuk memberikan gambaran mengenai tata cara pengelolaan penjualan online ini, maka tim tutor memberikan gambaran untuk menyelesaikan permasalahan mengenai pengelolaan penjualan online yaitu dengan mensimulasikan program aplikasi yang sudah dirancang oleh tim pengabdian masyarakat kepada anggota Adpers Art Community. Penjualan secara online merupakan pemasaran secara online dilakukan melalui system computer online interaktif yang menghubungkan pelanggan dengan penjual secara elektronik (Nursari \& Immanuel, 2018).

Para peserta sosialisasi mengajukan pertanyaan-pertanyaan terkait dengan aplikasi program yang akan diterapkan. Dengan antusiasme peserta yang begitu tinggi menunjukkan bahwa peserta sangat tertarik dengan sosialisasi yang diadakan.

Pada akhir kegiatan pengabdian masyarakat ini, tim pengabdian masyarakat menguji pemahaman para peserta terhadap materi yang disampaikan yaitu dengan memberikan pertanyaan-pertanyaan atau kuesioner yang sesuai dengan materi yang diberikan.

Tabel 4 Survei Setelah Sosialisasi

\begin{tabular}{clc}
\hline No & \multicolumn{1}{c}{ Indikator } & Hasil \\
\hline $\mathbf{1}$ & $\begin{array}{l}\text { Kemampuan } \\
\text { menggunakan media } \\
\text { penjualan online }\end{array}$ & $75 \%$ \\
\hline $\mathbf{2}$ & $\begin{array}{l}\text { Kemampuan mengelola } \\
\text { penjualan secara online }\end{array}$ & $80 \%$ \\
\hline $\mathbf{3}$ & $\begin{array}{l}\text { Kemampuan melakukan } \\
\text { strategi marketing } \\
\text { secara online }\end{array}$ & $87 \%$ \\
\hline
\end{tabular}

Hasil kuesioner peserta pada kegiatan ditampilkan pada deskripsi berikut ini. Sebanyak (75\%) responden mampu menggunakan media penjualan online, $80 \%$ responden mampu mengelola penjualan secara online dan sebesar $87 \%$ responden mampu melakukan strategi marketing secara online.

\section{Simpulan dan Rekomendasi}

Dalam kegiatan pengabdian masyarakat ini para tutor sebelumnya melakukan survey terlebih dahulu untuk melihat kondisi dan permasalahan yang ada di Mitra, setelah mengetahui secara jelas kondisi yang ada di mitra, maka tim pengabdian masyarakat membuat sebuah sistem informasi pengelolaan penjualan berbasis online, dimana website ini dimaksudkan untuk mempermudah sistem pengelolaan penjualan barang-barang yang ada di Adpers Art Community. Setelah website sudah 
dapat berfungsi, maka website tersebut diperkenalkan oleh tim pengabdian masyarakat sekaligus dilakukan workshop penggunaan dan pengelolaan penjualan secara online hingga startegi marketing yang dilakukan. Upaya ini dimaksudkan untuk melakukan jangkauan penjualan yang mendunia. Berdasarkan hasil survey sosialisasi penggunaan website penjualan online ini maka didapatkan hasil survey sebagai berikut, Sebanyak (75\%) responden mampu menggunakan media penjualan online, $80 \%$ responden mampu mengelola penjualan secara online dan sebesar $87 \%$ responden mampu melakukan strategi marketing secara online.

\section{Acknowledgements}

Terima kasih kepada LPPM Universitas Bina Sarana Informatika yang telah memberikan wadah untuk kegiatan pengabdian kepada masyarakat ini, seluruh anggota Adpers Art Community yang telah meluangkan waktu kepada kami untuk memberikan sosialisasi dalam tata cara pengelolaan website penjualan online, dan kepada semua pihak-pihak yang terlibat dalam kegiatan pengabdian kepada masyarakat ini.

\section{Daftar Pustaka}

Hastanti, R. P., Purnama, B. E., \& Wardati, I. U. (2015). Sistem Penjualan Berbasis Web ( E-Commerce ) Pada Tata Distro Kabupaten Pacitan. Bianglala Informatika, 3(2), 1-9.

Hidayat, M. K., \& Ningrum, R. C. P. (2017). Sistem Informasi Penjualan Online Pada Toko Yusuf Bekasi. Indonesian Journal on Computer and Information Technology (IJCIT), 2(2), 24-30.

Nursari, S. R. C., \& Immanuel, Y. (2018). Perancangan Sistem Informasi Penjualan Online. CCIT Journal, 11(1), 102-114. Retrieved from https://ejournal.raharja.ac.id/index.php/ccit/article/view/563

Susandi, D., \& Sukisno, S. (2017). Sistem Penjualan Berbasis E-Commerce Menggunakan Metode Objek Oriented pada Distro Dlapak Street Wear. JSiI (Jurnal Sistem Informasi), 4, 5-8. https://doi.org/10.30656/jsii.v4i0.368

Syah, R., Iqbal, M., \& Elveny, M. (2014). Pembangunan Aplikasi E-Commerce Dalam Menunjang Penjualan Produk Pada Cv.Riztech. Jurnal Penelitian Teknik Informatika, 4, 1-80.

Thousani, H. F., Fauzi, A., \& Sunarti, S. (2015). Upaya Pengembangan E-Business Dalam Pemasaran Produk Secara Internasional (Studi pada Akademi Bisnis Online Indonesia Surabaya). Jurnal Administrasi Bisnis, 23(1), 1-8.

Zubaidi, A., Wijaya, I. G. P. S., Irmawati, B., \& Arimbawa, I. W. A. (2019). Pengenalan Teknologi Internet of Things (Iot) Untuk Menyelesaikan Permasalahan Di Sekitar Bagi Siswa-Siswi Sekolah Menengah Atas Negeri 7 Mataram. Abdi Insani, 6(1), 80. https://doi.org/10.29303/abdiinsani.v6i1.193 